\title{
Human Health, Rights and Wind Turbine Deployment in Canada
}

\author{
Carmen Krogh1, Brett Horner² \\ ${ }^{1}$ Independent Health Researcher, Killaloe, Ontario, Canada \\ ${ }^{2}$ Independent Researcher, Killaloe, Ontario, Canada \\ Email: Carmen.krogh@gmail.com,brett.s.horner@gmail.com
}

How to cite this paper: Krogh, C. and Horner, B. (2017) Human Health, Rights and Wind Turbine Deployment in Canada. Open Journal of Social Sciences, 5, 166-185. https://doi.org/10.4236/jss.2017.55012

Received: March 16, 2017

Accepted: May 14, 2017

Published: May 17, 2017

Copyright (c) 2017 by authors and Scientific Research Publishing Inc. This work is licensed under the Creative Commons Attribution International License (CC BY 4.0).

http://creativecommons.org/licenses/by/4.0/

\begin{abstract}
Canada has ratified international conventions which recognize the individual's right to the enjoyment of the highest attainable standard of health. Despite the adoption of these covenants governments sometimes support policies and practises which trade off individual human health with other conflicting interests. This review evaluates the individual's right to health against government policies and practices which support wind energy deployment in Canada. Our analysis presents government documents, peer reviewed literature, and other references which support the conclusion that wind energy deployment in Canada can be expected to result in avoidable harm to human health. This harm conflicts with contemporary health and social justice principles. Governments have a responsibility to help Canadians maintain and improve their health by generating effective responses for the prevention of avoidable harm. Individuals have a right to make informed decisions about their health. Knowledge gaps and potential risks to health should be fully disclosed. Individuals should not be exposed to industrial wind turbines without their informed consent.
\end{abstract}

\section{Keywords}

Wind Turbines, Policies and Practices in Canada, Harm to Human Health, Human Rights, Social Justice

\section{Introduction}

Individuals in Canada enjoy the right to the highest attainable level of health and governments have a responsibility to help Canadians achieve this right. To this end Canada has developed health promotion frameworks aimed at achieving health for all. At the same time conflicting interests inherent in our society can result in inadequate health policies and practices and undermine the health and 
quality of life of many Canadians. The deployment of industrial wind turbines (IWTs) in Canada presents a contemporary example of the individual's right to health in conflict with competing interests.

The global installed wind energy capacity has experienced rapid growth since 2001 [1]. Coinciding with the operation of IWTs, some individuals living in proximately report adverse health effects [2]. These negative effects can be avoided if IWTs are sited away from residents.

In Canada IWT deployment has been supported by government policy [3] [4], major government funding programs [3] [4] and legislation [5]. In addition some governments in Canada have developed IWT noise criteria which can be expected to result in adverse health effects [6] [7] [8] [9]. In some cases Canadian families reporting IWT adverse health effects have: abandoned their homes; or been billeted away from their homes; or hired legal counsel to successfully reach a financial agreement with the wind energy developer [2].

This review considers the definition of "health" adopted by Canada and the individual's fundamental right to its attainment. Policies and practices which support wind energy deployment in Canada are evaluated in the context of modern health frameworks and the responsibility of government to help maintain and improve the health of Canadians.

\section{Materials and Methodology}

A review of relevant treaties and covenants adopted by Canada since 1948 were evaluated to establish the following health principles:

- The definition of health

- The individual's right to health

- The individual's right to informed consent

- The role of governments to promote and protect health

Government frameworks were explored to understand, how Canadians can best achieve health, and that conflicting interests can undermine the health and quality of life of many Canadians.

Documents obtained from government publication, websites and Access to Information and Privacy (ATIP) requests were used to chronicle IWT policies and practises undertaken by government in Canada since 2005. These government policies and practices were evaluated against key health principles and health promotion frameworks adopted by Canada.

References cited in this review were retrieved from a variety of sources including:

- References published by governmental authorities in Canada,

- Documents obtained by federal Access to Information and Privacy (ATIP) requests,

- References published by, or for, members of the Canadian wind energy industry,

- References published by international health organizations,

- Peer reviewed literature, 
- Grey literature, and

- Other references.

\section{Canada and Health Principles}

Canada has a historical role in the development of modern health doctrine intended to nurture a policy environment that supports health and where individuals of all ages and backgrounds can have an equitable chance of achieving health.

\subsection{Canada, Health and Human Rights}

Canada has described its governance structure as:

... a democratic constitutional monarchy, with a Sovereign as head of State and an elected Prime Minister as head of Government. Canada has a federal system of parliamentary government: Government responsibilities and functions are shared between federal, provincial and territorial governments [10].

Health Canada is the Federal department responsible for helping Canadians maintain and improve their health, while respecting individual choices and circumstances [11].

Canada has a universal health-care system where Canadian citizens and permanent residents enjoy the option of public health insurance [12] and The Canadian Charter of Rights and Freedoms guarantees "everyone has the right to life, liberty and security of the person and the right not to be deprived thereof except in accordance with the principles of fundamental justice" [13].

A Canadian Deputy Minister of Health, Dr. Brock Chisholm, became the first Director General of the World Health Organization (WHO) [14] [15] and was a co-draftee of the WHO definition of health [15].

Canada, including both Health Canada and the Public Health Agency of Canada, continues to support the definition of health established by the WHO's ... constitution in 1948: Health is "a state of complete physical, mental and social well-being and not merely the absence of disease or infirmity [16].

The stated objective of the WHO is "...the attainment by all peoples of the highest possible level of health" [17]. Canada has the distinction of being the Third Member State to ratify the WHO constitution [14] which in addition to providing Canada's definition of "health" declares "The enjoyment of the highest attainable standard of health is one of the fundamental rights of every human being without distinction of race, religion, political belief, economic or social condition" [17].

Canada is also a party to international human rights treaties [18] which recognize the individual's rights to the highest attainable standard of health [19] [20]. 


\subsection{Health Promotion, Prevention and Protection}

In 2005 Health Canada identified one of the "Current Issues of Greater Significance for Canada" to be "non-communicable disease prevention and control" [14]. Protection of “...Canadians from avoidable risks” remains a goal of Health Canada [11].

In 2012 The Public Health Agency of Canada confirmed Canada's approach to health is consistent [16] with the United Nations Political Declaration of the High-level Meeting of the General Assembly on the Prevention and Control of Non-communicable Diseases which recognizes the "...the primary role and responsibility of Governments in responding to the challenge of non-communicable diseases and the essential need for the efforts and engagement of all sectors of society to generate effective responses for the prevention and control of noncommunicable diseases" [21].

In addition to supporting the WHO definition of health Canada has adopted “...two key documents... instrumental in focusing policy and program discussions on how health is created and how health can be achieved equitably by society as a whole" [22]. The two key documents are the Ottawa Charter on Health Promotion and Health Canada's Achieving Health for All: A Framework for Health Promotion [22].

The Ottawa Charter on Health Promotion “...defined the fundamental prerequisites for health as peace, shelter, education, food, income, a stable eco-system, sustainable resources, social justice and equity. It also recognized that access to these prerequisites cannot be ensured by the health sector alone. Rather, coordinated action is required among all concerned, including governments (health and other social and economic sectors) non-governmental organizations, industry and the media" [22].

Health Canada's Achieving Health for All: A Framework for Health Promotion called attention to three key health promotion challenges: reducing inequities in health; increasing the prevention of disease; and enhancing the capacity to cope with chronic disease and disability. The Framework recognises the need for a multi-sector cooperation "...to ensure that the collective policy environment is one that supports health" [22].

Canada recognizes the rights of individuals to be protected from arbitrary scientific experimentation and is a party to [18] the International Covenant on Civil and Political Rights which provides “...no one shall be subjected without his free consent to medical or scientific experimentation" [23].

\section{Health Risks of Noise Includes Annoyance}

Health Canada's "broad mandate to protect and maintain the health of Canadians-includes protecting people from risks in the environment they work, live and play..." and the "...public expects government to mitigate these risks ..." [24].

Exposure to IWT noise has been identified as a plausible cause of reported health effects [2]. 
The main health risks of noise identified by WHO are:

-pain and hearing fatigue;

-hearing impairment including tinnitus;

-annoyance;

- interferences with social behaviour (aggressiveness, protest and helplessness);

-interference with speech communication;

-sleep disturbance and all its consequences on a long and short term basis;

-cardiovascular effects;

-hormonal responses (stress hormones) and their possible consequences on human metabolism (nutrition) and immune system;

-performance at work and school [25].

Annoyance from noise is acknowledged to be a health effect [26] [27] [28] [29]. Health Canada explained that according to the WHO “... health should be regarded as "a state of complete physical, mental and social well being and not merely the absence of disease or infirmity" Under this broad definition, noise induced annoyance is an adverse health effect" [28].

The WHO pan-European LARES study explored impacts of annoyance in a sample that included children, adults and elderly participants. "The results of the LARES study - with regard to criteria for causal relations - confirmed, on an epidemiological level, an increased health risk from chronic noise annoyance" [30]. Consequently chronically strong annoyance must be classified as a serious human health risk [30].

The burden of disease of annoyance has been estimated. "Loss of health in populations is measured in disability-adjusted life years (DALYs), which is the sum of years of life lost due to premature death and years lived with disability" [31]. In western European countries, noise-induced annoyance is estimated to account for 587000 DALYS. [32]

\section{IWTs and the Well-Known Stress Effects of Noise}

Some individuals residing in proximity to IWTs report experiencing adverse health effects.

Reported health effects include, but are not limited to, annoyance, sleep disturbance, stress-related health impacts and reduced quality of life. [2] [33]-[44]. Similarly occupational workers and technicians exposed to IWTs also have reported negative health effects [45]-[51].

IWT noise (unwanted sound), visual impacts (shadow flicker), stray voltage and socio-economic impacts are identified as plausible causes of adverse effects [2]. The National Research Council (2007) reports “...to the extent that windenergy projects create negative impacts on human health and well-being, the impacts are experienced mainly by people living near wind turbines who are affected by noise and shadow flicker" [52].

Pierpont (2009) documented symptoms reported by individuals exposed to IWTs to include: sleep disturbance, headache, tinnitus, ear pressure, dizziness, vertigo, nausea, visual blurring, tachycardia, irritability, problems with concen- 
tration and memory, and panic episodes associated with sensations of internal pulsation or quivering when awake or asleep [33]. Pierpont (2009) coined these symptoms "Wind Turbine Syndrome" [33].

In 2009 The American Wind Energy Association and Canadian Wind Energy Association (CanWEA) co-sponsored a literature review which “...undertook extensive review, analysis, and discussion of the large body of peer reviewed literature on sound and health effects in general, and on sound produced by wind turbines" [53]. Based on this review Colby et al. (2009) reported "Wind Turbine Syndrome" symptoms "... are not new and have been published previously in the context of "annoyance"..." and are the "...well-known stress effects of exposure to noise ..." [53]. Jeffery et al. (2014) confirmed the reported "...effects from exposure to IWTs are consistent with well-known stress effects from persistent unwanted sound" [2].

In 2011 CanWEA advised the public "the association has always acknowledged that a small percentage of people can be annoyed by wind turbines in their vicinity.... When annoyance has a significant impact on an individual's quality of life, it is important that they consult their doctor" [54]. McMurtry and Krogh (2014) [55] present a diagnostic criteria tool to assist practicing physicians who are presented with patients impacted by IWT annoyance [56].

\section{Discussion}

\subsection{Health Principles and Conflicting Interests}

The Ottawa Charter on Health Promotion "...highlighted the fact that health promotion action goes beyond the health care sector, emphasizing that health should be on the policy agenda in all sectors, and at all levels of government" [57].

Our review of government publications, documents and websites confirm the following health principles have been adopted and supported by Canada.

- Health is a state of complete physical, mental and social well-being and not merely the absence of disease or infirmity.

- Individuals have a fundamental human right to the highest attainable standard of health.

- Governments have a shared a responsibility to help Canadians maintain and improve their health, while respecting individual choices and circumstances.

- A primary role and responsibility of government is to generate effective responses for the prevention and control of non-communicable diseases.

- No one shall be subjected without their free consent to medical or scientific experimentation.

While these principles provide underpinning for a socially just health doctrine, Health Canada's "Achieving Health for All” identifies major challenges which are not being adequately addressed by current health policies and practices including “...various forms of preventable diseases and injuries continue to undermine the health and quality of life of many Canadians" [58]. 
Tobacco is highlighted as a historical example of how government policy can trade off preventable harm for competing economic interests.

Conflicting interests may exist between sectors. Such conflicts are intrinsic to our society. Take the example of tobacco. We are proponents of a smokefree environment. On the other hand, there are Canadian farmers who cultivate this product for their livelihood. Changes in tobacco policies have implications for farmers and smokers alike. In this instance the creation of healthy public policy necessitates responding to a situation with serious health as well as economic implications [58].

This conflict between health and economic interests has continued to exist. In 2012, Health Canada reported "each year in Canada, second-hand smoke causes the death of at least 800 non-smokers, due to lung cancer and heart disease" [59]. Despite this avoidable harm, production of tobacco and tobacco products remain an active sector in Canada's economy. Statistics Canada reported Canadian manufacturers produced 21.5 billion cigarettes in 2014 [60].

Achieving Health for All acknowledges “...existing policies and practices are not sufficiently effective to ensure that Canadian men and women of all ages and backgrounds can have an equitable chance of achieving health..." [58]. We explore this understanding by reviewing government policies and practices for addressing potential health risks associated with two contemporary exposures; tanning equipment and IWTs.

\subsection{Tanning Equipment, Health Promotion and Protection}

The Radiation Emitting Devices Act (REDA) is federal legislation that regulates devices which emit energy in the form of electromagnetic waves or acoustical waves [61]. Health Canada has identified both tanning equipment [62] and IWTs [6] [7] [8] [63] as devices regulated under the authority of the REDA.

Exposure to tanning equipment in Canada typically occurs only with the consent of individuals. In 2014 Health Canada in collaboration with the Federal Provincial Territorial Radiation Protection Committee, released A Guideline published for Tanning Salon Owners, Operators and Users [64]. The Guideline identified health risk associated with tanning equipment and focused on prevention of avoidable harm recommending the use of tanning equipment, particularly by minors, be discouraged [64]. Health Canada has also strengthened "... the labelling requirements for tanning beds to better inform consumers about the health risks associated with the use of these devices" [65] and in 2014 new Ontario legislation came into effect which, among other things, bans the use of tanning beds by youth under 18 years of age [66].

These policies and practises demonstrate shared responsibility by multiple levels of government to help Canadians maintain and improve their health by: generating responses for the prevention and control of non-communicable diseases, protecting vulnerable populations; and providing disclosure of risks so that individuals can make informed decisions about their health. 


\subsection{Industry Led, Government Supported Wind Energy}

After considering the evidence and testimony presented by 26 witnesses [67], a 2011 Ontario environmental review tribunal decision acknowledged IWTs can harm human health stating:

This case has successfully shown that the debate should not be simplified to one about whether wind turbines can cause harm to humans. The evidence presented to the Tribunal demonstrates that they can, if facilities are placed too close to residents. The debate has now evolved to one of degree [68].

However, unlike tanning equipment, the use of IWTs has been encouraged by government in Canada. The Government of Canada has provided long time support for the wind energy. In 2005 Project Green indentified that in addition to environmental benefits, Canada's expanded Wind Power Production Incentive will "...build a new economic sector and position Canada to be a leader in a vibrant wind energy industry in North America and internationally" [4].

A 2006 Health Canada commissioned report identified wind energy as a "screened in" greenhouse gas mitigation technology supported by "Federal Climate Change Policy" and major funding programs [3].

As Canada emerged from the 2008 global economic crisis, the Government of Canada focused on jobs and the economy [69]. The Government of Canada's priorities included promoting economic growth, the continued expansion of Canada's international trade and creation of green jobs befitting its “... growing stature as a clean energy superpower" [69].

In 2012 Health Canada reported "Natural Resources Canada and Industry Canada in collaboration with industry stakeholders" [70] developed the Wind Technology Road Map (WindTRM). Natural Resources Canada describes WindTRM as "... an industry-led, government-supported initiative that has developed a long-term vision for the Canadian wind energy industry and identified the major technology gaps and priorities to achieve a major increase in deployment of wind energy in Canada" [71].

The WindTRM projected the creation of a minimum of 52,000 green jobs and “...also recognize[d] that Canada is competing for this investment with many other jurisdictions and that it is critical for Canada to establish a competitive investment policy framework. If no action is taken, Canadian industry will miss out on a huge part of the value chain that will be created in achieving the vision" [71].

\subsection{Government IWT Noise Criteria}

CanWEA describes itself as the "voice of Canada's wind energy industry" [72] and was a WindTRM participant [71]. In 2004 CanWEA advised “...noise regulations can have a significant impact on wind turbine spacing, and therefore the cost of wind generated electricity ..." [73]. The President of CanWEA has also explained IWTs are sited in populated areas because developers need access to transmission infrastructure [74]. 
Regarding noise-induced health effects:

Health Canada considers the following noise-induced endpoints as health effects: noise-induced hearing loss, sleep disturbance, interference with speech comprehension, complaints, and change in percent highly annoyed (\%HA) [75].

Commenting on IWTs Health Canada has repeatedly advised "annoyance with noise is a reliable and widely accepted indicator of health effects due to environmental noise" [76].

Health promotion frameworks and principles adopted by Canada suggest government IWT noise criteria would be informed by definitive scientific research and would not be expected to result in increased adverse health effects. This has not been the case in Ontario where provincial IWT noise guidelines have been developed [77]. Based on current knowledge, the sound from IWTs at the levels experienced at typical distances in Ontario is expected to result in a non-trivial percentage of persons being highly annoyed and contribute to stress related health impacts [9].

Health Canada does not have noise guidelines or enforceable noise thresholds or standards [75] however in 2007 and 2008 Health Canada published an IWT noise "justification" for $45 \mathrm{dBA}$ and predicted an increase in \%HA from 1.1 to 7.6 percent [6] [7] [8]. Some Canadian provinces have applied the Health Canada IWT 45 dBA noise criteria. For example the Province of Nova Scotia “....applies the federal guidelines for noise when granting approvals" [78].

Health Canada's predicted increase in \%HA is not supported by other IWT noise research and appears to be underestimated. IWTs sound has been consistently shown to be perceived by humans to be more annoying than transportation or industrial noise at comparable sound pressure levels [42]. Annoyance from IWT noise starts at dBA sound pressure levels in the low 30's and rises at 35 dBA [42] [79] [80]. Dose response data for IWTs suggest, at a highest allowed immission level of $45 \mathrm{~dB}(\mathrm{~A})$ it could be expected that “... less than $14 \%$ of the exposed population to be highly annoyed indoors by wind turbines and less than $29 \%$ to be highly annoyed outdoors" [81].

\subsection{Health Canada IWT Noise Initiatives and Challenges}

In 2005 Project Green and Health Canada and identified that

[t]here is a need to develop a federal framework or mechanism to ensure health impacts of new technologies or other mitigation measures are assessed before they are widely deployed or commercialized [4] [24].

Health Canada identified challenges to meeting this need including "competition for resources for research and assessment leaves many health concerns and potential risks unaddressed" and as a solution proposed to "...expand government partnerships and involve private sector in environmental health research, in defining priorities and participating in surveillance.” [24] 
The 2010 Wind TRM declared “...members of the Steering Committee, government and our industry will be using this roadmap to direct the actions that are necessary for Canada to develop its vast wind resources" [71]. One of the "key action items" detailed in the Wind TRM calls for Government and Industry collaboration to develop and maintain government documents that address concerns raised about wind energy projects including that of noise, infrasound and other [71].

Health Canada became a member of the Interdepartmental Wind Technology Road Map Committee [82] created by Natural Resources Canada to assist in the implementation of Canada's WindTRM [83].

Also in 2010, Health Canada proposed the formation of the Federal, Provincial, Territorial (FPT) Working Group to contribute to the development of national guidelines on IWT noise [70] [78] [84]. Health Canada had proposed a 45dBA IWT noise criterion for these guidelines [78]. The FPT Working Group was suspended in January 2012 owing to the lack of consensus among the members [70]. One FPT member expressed concern that limits of less than $45 \mathrm{dBA}$ would result in a loss of prospective IWT sites and limit expansion of an existing project [78]. Another FPT Working Group member commenting on the guidelines stated “...I do not see these as health-based. I think we would be on more solid ground if the basis of these guidelines was something other than health" [78]. In February 2012, "Health Canada Policy and Research Approach for Wind Turbine Noise” declared Health Canada “...will explore research options and release guidelines only when knowledge gaps are filled" [82].

In 2012 Health Canada advised “... there is ongoing scientific uncertainty on whether there are other, possibly indirect, health effects associated with wind turbine noise, and if so, to what extent ... All existing studies have limitations, and there is a need for further research in this area." [70]

In June 2012, after years of providing advice on IWT noise, Health Canada disclosed "Health Canada's ability to provide advice on noise impacts from WTs has been challenged..." [85] and officially announced its 1.8 million dollar Health Canada Wind Turbine Noise and Health study (Health Canada Study). The announcement acknowledged the Health Canada Study has "limitations", would be not be definitive and was intended to inform policy [85]. Also in 2012, the Canadian Council of Academies (CCA) was engaged by Health Canada to conduct an assessment of the literature into possible health impacts of IWTs [82].

November 2014 summary results of the Health Canada Study reported high levels of annoyance associated with increasing levels of IWT noise and “.... annoyance was found to be statistically related to several self-reported health effects including, but not limited to, blood pressure, migraines, tinnitus, dizziness, scores on the PSQI, and perceived stress" as well as related to "measured hair cortisol, systolic and diastolic blood pressure" [86]. Subsequently in 2015, the CCA released its review of the literature into possible health impacts of IWT noise [29] and announced “...annoyance can be caused by wind turbine noise- 
a clear adverse health effect" [87]. While some IWT knowledge gaps had been previously identified [70] [88] [89] the CCA identified additional gaps and issues [29] and concluded "technological development is unlikely to resolve, in the short term, the current issues related to perceived adverse health effects of wind turbine noise" [90].

\subsection{Exposure Without Consent}

Achieving Health for All describes a "New Vision of Health" which “...recognizes freedom of choice and emphasizes the role of individuals and communities in defining what health means to them." [58]

Canada has ratified [18] the covenant that no one shall be subjected without their free consent to medical or scientific experimentation [23]. Some individuals in Canada may enter into contractual agreements with wind energy developers and accept potential risks of IWT exposure [91] [92]. However, unlike exposure to tanning equipment, exposure to ITWs can also be imposed on individuals without consent. Government has approved deployment of IWTs despite municipal governments having declared their jurisdictions to be unwilling hosts of wind energy projects [93] [94].

Individuals continue to be exposed without consent, and have formed part of the sample pool of potential subjects from which researchers have drawn data and/or biological samples for government sponsored IWT health studies [86] [95].

\subsection{Government Responsibility and Future Liability}

A 2006 Health Canada memorandum identified that "[g]reenhouse gas mitigation technologies and measures... may pose unintentional threats to human health..." and "...the Government of Canada has a responsibility to ensure that these technologies do not negatively impact the health of Canadians" [96]. Another Health Canada document reported "it is unclear if the recommendations from these funding programs ... are in the best interest of Canadians and also protect the Crown from future liabilities resulting from the widespread application of new technologies" [97].

In 2005, Health Canada had acknowledged Canada's Climate Change Plan had "...no systematic assessment of potential health risks of new processes, technologies or products..." and stated "we cannot afford to wait until the health of Canadians is affected before we act. We have the means, tools and knowledge to become proactive in protecting the health of our citizens, in particular those most at risk" [24]. Health Canada presented a "Health and Environment Framework" which was to focus on "health outcomes" and "population groups at risk" [24].

WHO identify children and elderly as populations more vulnerable to noise [98] and the Tri-Council Policy Statement: Ethical Conduct for Research Involving Humans dictates children, at all stages of development, and the elderly shall not be inappropriately excluded from research solely on the basis of their 
age [99]. However the Health Canada IWT Study excluded the vulnerable populations of children and elderly over 79 years [86].

\subsection{Blaming the Victim}

WHO reports healthy public policy “...puts health on the agenda of policy makers in all sectors and at all levels, directing them to be aware of the health consequences of their decisions and to accept their responsibilities for health" [100] and Achieving Health for All points out

... we cannot invite people to assume responsibility for their health and then turn around and fault them for illnesses and disabilities which are the outcome of wider social and economic circumstances. Such a "blaming the victim" attitude is based on the unrealistic notion that the individual has ultimate and complete control over life and death [58].

In 2009, the Minister of Labour advised

Health Canada provides advice on the health effect of noise and low-frequency electric and magnetic fields from proposed wind turbine projects, particularly for environmental assessments done under the Canadian Environmental Assessment Act. To date, their examination of the scientific literature on wind turbine noise is that the only health effect conclusively demonstrated from exposure to wind turbine noise is an increase of selfreported general annoyance and complaints (i.e., headaches, nausea, tinnitus, vertigo) [101].

Some commentators suggest negative attitudes toward IWTs may contribute to reported annoyance [102]. However, researchers have found that IWTs were initially welcomed into the communities for their perceived environmental [35] or economic [37] benefits. Krogh (2011) wrote.

Individuals report they welcomed IWTs into their community and the negative consequences were unexpected... When the health symptoms became apparent, there was an expectation that authorities and/or the IWT developer would resolve the issues. Individuals report their distress intensified when attempts to obtain recognition of their situation failed. An unexpected lack of response from a cross section of society, including government officials, industry, medical practitioners led to an exacerbation of their situation [43].

Jeffery et al. (2014) reports the characteristics of IWT noise "...that are identified as plausible causes for reported health effects include amplitude modulation, audible low-frequency noise (LFN), infrasound, tonal noise, impulse noise and night-time noise" [2]. While suggesting infrasound impacts may be a non issue Health Canada's lead IWT noise investigator stated in 2013 “...subject matter experts seem to agree... that more attention should be directed towards low frequency noise $(16-160 \mathrm{~Hz})$, tones and amplitude modulation and how to better 
model these impacts, including how these change across the seasons" [103].

Governments aware that the consequences of their IWT noise criteria include a predicted increase in \%HA must accept responsibility for their health decisions and advice. On the other hand individuals exposed to IWTs cannot be faulted for ill health when the conclusively demonstrated health effects are a predicted outcome of government supported IWT noise criteria.

\subsection{Summation}

The case of wind energy deployment in Canada presents a contemporary example of individual achievement of health competing with conflicting interests intrinsic in our society. Canada has ratified the WHO constitution which recognizes the individual's right to health [17]. On the other hand, the government also supports a major increase in the deployment of wind energy in Canada [4] [71] IWT noise criteria have health implications for individuals exposed to IWTs as well economic implications for industry.

A primary role and responsibility of government is to generate effective responses for the prevention and control of non-communicable diseases. To be effective prevention responses should be informed by systematic assessments of potential health risks. Such assessments should commence with a comprehensive review of the literature and identification of all knowledge gaps. Ethical animal research targeted at resolving research gaps may then be considered. Any subsequent human research must be conducted only with the informed consent of the subject. Once definitive research has conclusively resolved the knowledge gaps, a IWT dose response relationship can be established to help inform standards aimed at preventing adverse health effects.

Health Canada's approach to IWT noise presents a different process. Health Canada acknowledged that "preferably the proposed criteria would be based on a dose response relationship that was specific to wind turbines" [6]. However Health Canada elected to base its 45dBA IWT noise criteria on traffic noise [6] [7] [8] and predicted an increase in the \%HA. Recommendations which are predicted to result in adverse health effects conflict with governments' responsibility to help Canadians maintain and improve their health as well as the individual's fundamental human right to the highest attainable standard of health.

Health Canada's subsequent acknowledgment that its “... ability to provide advice on noise impacts from wind turbines has been challenged by limited scientific research and knowledge gaps..." [70] suggests the Government of Canada has not fulfilled its stated responsibility to ensure carbon mitigation technologies do not negatively impact the health of Canadians. The continued exposure of non consenting individuals to IWTs conflicts the covenant ratified by Canada that no one shall be subjected without their free consent to medical or scientific experimentation.

Health Canada, has identified the failure of government to ensure technologies do not negatively impact the health of Canadians may expose the Crown to future liabilities. 


\section{Conclusions}

A review of key health principles adopted and supported by the Government of Canada was conducted. These key principles were contrasted against Government policies and practices which support wind energy deployment in Canada.

Government documents, peer reviewed literature, and other references presented support the conclusion that wind energy deployment in Canada can be expected to result in harm to human health. The resulting harm is avoidable and conflicts with the individual's fundamental human right to the highest attainable standard of health.

Governments have a responsibility to help Canadians maintain and improve their health by generating effective responses for the prevention of avoidable harm. Individuals have a right to make informed decisions about their health. IWT knowledge gaps and potential risks to health should be fully disclosed. Individuals should not be exposed to IWTs without their informed consent.

\section{Acknowledgements}

The authors thank the reviewers for their comments during the review process.

\section{Financial Support and Sponsorship}

None.

\section{Conflicts of Interest}

There are no conflicts of interest.

\section{References}

[1] Global Wind Energy Council (2017) Global Wind Statistics 2016. http://www.gwec.net/wp-content/uploads/vip/GWEC_PRstats2016_EN_WEB.pdf

[2] Jeffery, R.D., Krogh, M.E. and Horner, B. (2014) Industrial Wind Turbines and Adverse Health Effects. Canadian Journal of Rural Medicine, 19, 21-26.

[3] Marbek Resource Consultants Ltd. (2006) Addressing the Health Risks of Climate Change Mitigation Technologies: A Discussion Paper Final Report Submitted to Health Canada. Marbek Resource Consultants Ltd., Ottawa.

[4] Government of Canada (2005) Project Green, Moving Forward on Climate Change a Plan for Honouring Our Kyoto Commitment.

[5] Government of Ontario (2009) An Act to Enact the Green Energy Act, 2009 and to Build a Green Economy, to Repeal the Energy Conservation Leadership Act, 2006 and the Energy Efficiency Act and to Amend Other Statutes. Government of Ontario, Toronto. https://www.ontario.ca/laws/statute/s09012\#

[6] Keith, S.E., Michaud, D.S. and Bly, S.H.P. (2007) A Proposal for Evaluating the Potential Health Effects of Wind Turbine Noise for Projects under the Canadian Environmental Assessment Act. Second International Meeting on Wind Turbine Noise, Lyon, 20-21 September 2007.

[7] Keith, S.E., Michaud, D.S. and Bly, S.H.P. (2008) A Justification for Using a 45 DBA Sound Level Criterion for Wind Turbine Projects. Canadian Acoustics, 36, 54.

[8] Keith, S.E., Michaud, D.S. and Bly, S.H.P. (2008) A Proposal for Evaluating the Po- 
tential Health Effects of Wind Turbine Noise for Projects under the Canadian Environmental Assessment. Journal of Low Frequency Noise, Vibration and Active Control, 27, 253-265. https://doi.org/10.1260/026309208786926796

[9] Howe Gastmeier Chapnik Limited (2010) Low Frequency Noise and Infrasound Associated with Wind Turbine Generator Systems: A Literature Review. Ministry of the Environment, Mississauga.

[10] Government of Canada (2011) Canada's System of Government.

[11] About Health Canada (2014). http://www.hc-sc.gc.ca/ahc-asc/index-eng.php

[12] Government of Canada (2017) Health Care in Canada. http://www.cic.gc.ca/english/newcomers/after-health.asp?_ga=1.76365141.19140826 70.1442157853

[13] Constitution Act (1982) Canadian Charter of Rights and Freedoms. http://laws-lois.justice.gc.ca/eng/Const/page-15.html

[14] Heath Canada (2005) About Health Canada, World Health Organization. Archived June 24, 2013. http://www.hc-sc.gc.ca/ahc-asc/intactiv/orgs/organi-eng.php

[15] WHO (1998) WHO: From Small Beginnings. World Health Forum, WHO, Geneva. http://whqlibdoc.who.int/analytics/WHForum_1988_9(1)_29-34.pdf

[16] Public Health Agency of Canada (2012) David Butler-Jones, Correspondence Concerning the World Health Organization Definition of Health.

[17] WHO (1948) Constitution of the World Health Organization. http://www.who.int/governance/eb/who_constitution_en.pdf

[18] Department of Justice (2016) International Human Rights Treaties to Which Canada Is a Party. http://www.justice.gc.ca/eng/abt-apd/icg-gci/ihrl-didp/tcp.html

[19] Convention on the Rights of the Child (1991) http://www.ohchr.org/Documents/ProfessionalInterest/crc.pdf

[20] International Covenant on Economic, Social and Cultural Rights (1976). http://www.ohchr.org/Documents/ProfessionalInterest/cescr.pdf

[21] Political Declaration of the High-Level Meeting of the General Assembly on the Prevention and Control of Non-Communicable Diseases (2011). Adopted at the 3rd plenary meeting. 19 September 2011.

http://www.who.int/nmh/events/un_ncd_summit2011/political_declaration_en.pdf

[22] Public Health Agency of Canada (2001) Population Health Promotion: An Integrated Model of Population Health and Health Promotion.

http://www.phac-aspc.gc.ca/ph-sp/php-psp/php2-eng.php\#Doing

[23] International Covenant on Civil and Political Rights (1976). http://www.ohchr.org/Documents/ProfessionalInterest/ccpr.pdf

[24] Glover, P. (2005) Innovation and Technology: Ensuring Health Benefits and Managing Risks for Canadians. Health Canada.

[25] World Health Organization Europe (2009) Noise. World Health Organization, Geneva.

[26] Berglund, B., Lindvall, T. and Schwela, D.H. (1999) Guidelines for Community Noise. World Health Organization, Geneva.

http://www.euro.who.int/en/health-topics/environment-and-health/noise/publicati ons

[27] Health Canada (2005) Community Noise Annoyance. http://www.hc-sc.gc.ca/hl-vs/alt_formats/pacrb-dgapcr/pdf/iyh-vsv/life-vie/commu nity-urbain-eng.pdf 
[28] Michaud, D.S., Keith, S.E. and McMurchy, D. (2005) Noise Annoyance in Canada. Noise Health. The World Residences at Sea, 7, 39-47.

[29] Council of Canadian Academies (2015) Understanding the Evidence: Wind Turbine Noise. The Expert Panel on Wind Turbine Noise and Human Health. http://scienceadvice.ca/uploads/eng/assessments\%20and\%20publications\%20and\% 20news\%20releases/wind-turbine-noise/windturbinenoisefullreporten.pdf

[30] Niemann, H., Bonnefoy, X., Braubach, M., Hecht, K., Maschke, C., Rodrigues, C. and Robbel, N. (2006) Noise-Induced Annoyance and Morbidity Results from the Pan-European LARES Study. Noise and Health, 8, 63-79. https://doi.org/10.4103/1463-1741.33537

[31] Smith, B.J., Tang, K.C. and Nutbeam, D. (2006) World Health Organization Health Promotion Glossary: New Terms, Health Promotion International Advance Access. http://www.who.int/healthpromotion/about/HP\%20Glossay\%20in\%20HPI.pdf?ua=1

[32] World Health Organization (2012) Environmental Health Inequalities in Europe. World Health Organization, Geneva.

http://www.euro.who.int/en/health-topics/environment-and-health/noise/publicati ons/2012/environmental-health-inequalities-in-europe.-assessment-report

[33] Pierpont, N. (2009) Wind Turbine Syndrome: A Report on a Natural Experiment. K-Selected Books, Santa Fe.

[34] Krogh, C., Gillis, L., Kouwen, N. and Aramini, J. (2011) Wind Voice, a Self-Reporting Survey: Adverse Health Effects, Industrial Wind Turbines, and the Need for Vigilance Monitoring. Bulletin of Science Technology \& Society, 31, 334-345. https://doi.org/10.1177/0270467611412551

[35] Shepherd, D., McBride, D., Welch, D., Dirks, K.N. and Hill, E.M. (2011) Evaluating the Impact of Wind Turbine Noise on Health-Related Quality of Life. Noise Health, 13, 333-339. https://doi.org/10.4103/1463-1741.85502

[36] Thorne, B. (2011) The Problems with Noise Numbers for Wind Farm Noise Assessment. Bulletin of Science Technology \& Society, 31, 262-290. https://doi.org/10.1177/0270467611412557

[37] Nissenbaum, M., Aramini, J. and Hanning, C. (2012) Effects of Industrial Wind Turbine Noise on Sleep and Health. Noise Health, 14, 237-243. https://doi.org/10.4103/1463-1741.102961

[38] Pedersen, E. and Persson, K.W. (2004) Perception and Annoyance Due to Wind Turbine Noise-A Dose Response Relationship. Journal of the Acoustical Society of America, 116, 3460-3470. https://doi.org/10.1121/1.1815091

[39] Pedersen, E. and Persson, W.K. (2007) Wind Turbine Noise, Annoyance and Self-Reported Health and Well Being in Different Living Environments. Occupational and Environmental Medicine, 64, 480-486. https://doi.org/10.1136/oem.2006.031039

[40] Onakpoya, I.J., O’Sullivan, J., Thompson, M.J. and Heneghana, C.J. (2015) The Effect of Wind Turbine Noise on Sleep and Quality of Life: A Systematic Review and Meta-Analysis of Observational Studies. Environment International, 82, 1-9. https://doi.org/10.1016/j.envint.2015.04.014

[41] Phipps, R., Amati, M., McCoard, S. and Fisher, R. (2007) Visual and Noise Effects Reported by Residents Living Close to Manawatu Wind Farms: Preliminary Survey Results.

[42] Pedersen, E., Bakker, R., Bouma, J. and Van den Berg, F. (2009) Response to Noise from Modern Wind Farms in the Netherlands. Journal of the Acoustical Society of America, 126, 634-643. https://doi.org/10.1121/1.3160293 
[43] Krogh, C.M.E. (2011) Industrial Wind Turbine Development and Loss of Social Justice? Bulletin of Science Technology \& Society, 31, 321-333. https://doi.org/10.1177/0270467611412550

[44] Copper, S. (2014) The Results of an Acoustic Testing Program. Cape Bridgewater Wind Farm, Melbourne.

[45] Swinbanks, M. (2015) Direct Experience of Low-Frequency Noise and Infrasound within a Wind Farm Community. 6th International Meeting on Wind Turbine Noise, Glasgow, 20-23 April 2015.

[46] Abbasi, M., Monnazzam, M.R., Zakerian, S.A. and Yousefzadeh, A. (2015) Effect of Wind Turbine Noise on Workers' Sleep Disorder: A Case Study of Manjil Wind Farm in Northern Iran. Fluctuation and Noise Letters, 14, 15 p.

[47] Abbasi, M., Monazzam, M.R., Ebrahim, M.H., Zakerian, S.A., Dehghan, S.F. and Akbarzadeh, A. (2016) Assessment of Effects of Wind Turbine on the General Health of Staff at Wind Farm of Manjil, Iran. Journal of Low Frequency Noise, Vibration and Active Control, 35, 91-98. https://doi.org/10.1177/0263092316628714

[48] Abbasi, M., Monazzam, M.R., Akbarzadeh, A., Zakerian, S.A. and Ebrahimi, M.H. (2015) Impact of Wind Turbine Sound on General Health, Sleep Disturbance and Annoyance of Workers: A Pilot-Study in Manjil Wind Farm, Iran. Journal of Environmental Health Science \& Engineering, 13, 71. https://doi.org/10.1186/s40201-015-0225-8

[49] Inagaki, T. and Nishi, Y. (2014) Analysis of Aerodynamic Sound Noise Generated by a Large-Scaled Wind Turbine and Its Physiological Evaluation. International Journal of Environmental Science and Technology, 12, 1933-1944. https://doi.org/10.1007/s13762-014-0581-4

[50] Ambrose, S.E., Rand, R.W. and Krogh, C.M.E. (2012) Wind Turbine Acoustic Investigation: Infrasound and Low-Frequency Noise-A Case Study. Bulletin of Science Technology \& Society published, 32. http://bst.sagepub.com/content/early/2012/07/30/0270467612455734

[51] Rand, R.E., Ambrose, S.E. and Krogh, C.M.E. (2011) Occupational Health and Industrial Wind Turbines: A Case Study. Bulletin of Science Technology \& Society, 31, 359. http://bst.sagepub.com/content/31/5/359

[52] National Research Council. (2007) Committee on Environmental Impacts of Wind Energy Projects, Environmental Impacts of Wind-Energy Projects. National Academies Press, Washington DC.

[53] Colby, W.D., Dobie, R., Leventhall, G., Lipscomb, D.M., McCunney, R.J., Seilo, M.T. and Søndergaard, B. (2009) Wind Turbine Sound and Health Effects: An Expert Panel Review. American Wind Energy Association and Canadian Wind Energy Association, Washington DC.

[54] The Canadian Wind Energy Association (2011) Responds to October 14, 2011 Statement by Wind Concerns Ontario. The Canadian Wind Energy Association, Ottawa.

[55] McMurtry, R.Y. and Krogh, C.M.E. (2014) Diagnostic Criteria for Adverse Health Effects in the Environs of Wind Turbines. The Royal Society of Medicine, 5, 1-5. https://doi.org/10.1177/2054270414554048

[56] McMurtry, R.Y. and Krogh, C.M. (2016) Response to McCunney et al:: Wind Turbines and Health: An Examination of a Proposed Case Definition. Noise Health, 18, 399-402. https://doi.org/10.4103/1463-1741.195805

[57] World Health Organization (1998) Health Promotion Glossary. http://www.who.int/healthpromotion/about/HPG/en/ 
[58] Health and Welfare Canada (1986) Achieving Health for All: A Framework for Health Promotion.

http://www.hc-sc.gc.ca/hcs-sss/pubs/system-regime/1986-frame-plan-promotion/in dex-eng.php

[59] Health Canada (2012) Second-Hand Smoke. It's Your Health. http://publications.gc.ca/collections/collection_2012/sc-hc/H13-7-25-2011-eng.pdf

[60] Statistics Canada (2014) Production and Disposition of Tobacco Products.

[61] Radiation Emitting Devices Act (1985). Current to September 10, 2015. http://laws-lois.justice.gc.ca/PDF/R-1.pdf

[62] Health Canada (2011) Tanning and Its Effects on our Health. It's Your Health. http://www.hc-sc.gc.ca/hl-vs/alt_formats/pdf/iyh-vsv/life-vie/tanning-bronzage-eng .pdf

[63] Michaud, D. (2013) Environmental Review Tribunal. Health Canada Wind Turbine Noise and Health Study, Ontario.

[64] Health Canada and the Federal Provincial Territorial Radiation Protection Committee (2014) A Guideline Published for Tanning Salon Owners, Operators and Users.

[65] Health Canada (2014) Government of Canada Announces Stronger Labelling Requirements for Tanning Beds-Warning Labels Remind Users about Skin Cancer Risk. http://news.gc.ca/web/article-en.do?nid=819389\&tp=1

[66] Ontario Ministry of Health and Long Term Care (2013) The Skin Cancer Prevention Act (Tanning Beds). http://www.health.gov.on.ca/en/public/programs/tanning/

[67] Jeffery, R.D., Krogh, C. and Horner, B. (2013) Adverse Health Effects of Industrial Wind Turbines (Commentary). Canadian Family Physician, 59, 473-475.

[68] Erickson, V. (2011) Environmental Review Tribunal. www.ert.gov.on.ca/files/201108/00000300-AKT5757C7CO026-BHH51C7A7SO026. pdf

[69] Prime Minister of Canada (2015) Priorities.

[70] Health Canada (2012) Briefing Note to the Ministers Office: Update on the Development of Federal-Provincial-Territorial Guidelines on Wind Turbine Noise.

[71] Wind Technology Road Map Summary Report (2010). http://www.nrcan.gc.ca/sites/www.nrcan.gc.ca/files/canmetenergy/pdf/fichier/8176 8/windtrm_summary_e.pdf

[72] About Canadian Wind Energy Association. http://canwea.ca/about-canwea/

[73] Canadian Wind Energy Association (2004) Letter to Neil Parish Re: Sound Level Limits for Wind Farms. Wind Energy Association, Ottawa.

[74] Hornung, R. (2010) Interview on Business News Network.

[75] Health Canada (2010) Useful Information for Environmental Assessments. Authority of the Minister of Health, Ottawa. http://publications.gc.ca/collections/collection_2015/sc-hc/H128-1-10-599-eng.pdf

[76] Health Canada. Obtained by Access to Information and Privacy Request.

[77] Ministry of the Environment (2008) Noise Guidelines for Wind Farms: Interpretation for Applying MOE NPC Publications to Wind Power Generation Facilities. Queen's Printer for Ontario, Toronto.

[78] Health Canada (2011) Federal-Provincial-Territorial (FPT) Working Group (FPT Working Group) for National Guidelines on Wind Turbine Noise. 
[79] Møller, H. and Pedersen, C.S. (2011) Low-Frequency Noise from Large Wind Turbines. The Journal of the Acoustical Society of America, 129, 3727-3744. https://doi.org/10.1121/1.3543957

[80] Michaud, D.S., Feder, K., Keith, S.E., Voicescu, S.A., Marro, L., et al. (2016) Exposure to Wind Turbine Noise: Perceptual Responses and Reported Health Effects. Journal of the Acoustical Society of America, 139, 1443-1454. https://doi.org/10.1121/1.4942391

[81] Janssen, S.A., Vos, H., Eisses, A.R. and Pedersen, E. (2011) A Comparison between Exposure-Response Relationships for Wind Turbine Annoyance and Annoyance Due to Other Noise Sources. Journal of the Acoustical Society of America, 130, 3746-3753. https://doi.org/10.1121/1.3653984

[82] Health Canada (2012) Health Canada Policy and Research. Approach for Wind Turbine Noise-A Presentation to the Science Advisory Board.

[83] Natural Resources Canada, Next Steps.

[84] Health Canada (2011) Obtained by Access to Information and Privacy Request.

[85] Michaud, D.S., Keith, S.E., Feder, K. and Bower, T. (2012) Health Impacts and Exposure to Wind Turbine Noise: Research Design and Noise Exposure Assessment. Inter-Noise 2012, New York, 19-22 August 2012, 3.

[86] Health Canada (2014) Wind Turbine Noise and Health Study: Summary of Results. http://www.hc-sc.gc.ca/ewh-semt/noise-bruit/turbine-eoliennes/summary-resume-e ng.php

[87] Council of Canadian Academies (2015) Expert Panel Finds that Annoyance Can Be Caused by Wind Turbine Noise-A Clear Adverse Health Effect.

http://www.scienceadvice.ca/uploads/eng/assessments\%20and\%20publications\%20a nd\%20news\%20releases/wind-turbine-noise/WindTurbineNoiseNewsReleaseEn.pdf

[88] Chief Medical Officer of Health (2010) The Potential Health Impact of Wind Turbines.

[89] Rideout, K., Copes, R. and Bos, C. (2010) Wind Turbines and Health. National Collaborating Centre for Environmental Health, Vancouver.

[90] Council of Canadian Academies (2015) Understanding the Evidence: Wind Turbine Noise. http://scienceadvice.ca/en/assessments/completed/wind-turbine-noise.aspx

[91] Lease Agreement for Wind Power between a Lessor and Lessee. "Schedule "B", Lease Agreement for Wind Power, Canada.

[92] Lease Agreement for Wind Power between a Lessor and Lessee. Surface Lease for Wind Power Project, Canada.

[93] Ferguson E. (2016) No "Veto" for Areas Opposed to Energy Projects, Kingston Whig-Standard.

http://www.thewhig.com/2016/03/31/no-veto-for-areas-opposed-to-energy-projects

[94] Wind Concerns Ontario. Not a Willing Host (2017). http://www.windconcernsontario.ca/not-a-willing-host/

[95] Jalali, L., Nezhad-Ahmadi, M.R., Gohari, M., Bigelow, P. and McColl, S. (2016) The Impact of Psychological Factors on Self-Reported Sleep Disturbance among People Living in the Vicinity of Wind Turbines. Environmental Research, 148, 401-410. https://doi.org/10.1016/j.envres.2016.04.020

[96] Government of Canada Memorandum. Marbek Discussion Paper: Addressing the Health Risks of Climate Change Mitigation Technologies: Discussion Paper.

[97] Health Canada. Assessing and Managing the Human Health Risks of Greenhouse Gases Mitigation Measures and Technologies. 
[98] World Health Organization (2012) Noise-Facts and Figures. http://archive.is/JqY9

[99] Canadian Institutes of Health Research, Natural Sciences and Engineering Research Council of Canada, and Social Sciences and Humanities Research Council of Canada (2014) Tri-Council Policy Statement: Ethical Conduct for Research Involving Humans, December 2014.

http://www.pre.ethics.gc.ca/pdf/eng/tcps2-2014/TCPS_2_FINAL_Web.pdf

[100] World Health Organization (1986) The Ottawa Charter for Health Promotion. First International Conference on Health Promotion, Ottawa, 21 November 1986. http://www.who.int/healthpromotion/conferences/previous/ottawa/en/

[101] The Honourable Rona Ambrose (2009) The Honourable Rona Ambrose, Minister of Labour.

[102] Knopper, L. and Ollson, C. (2011) Health Effects and Wind Turbines: A Review of the Literature. Environmental Health, 10, 78. https://doi.org/10.1186/1476-069x-10-78

[103] Michaud, D. (2013) Health Canada Trip Report. 5th International Wind Turbine Noise Conference, Denver, 27-30 August 2013.

Submit or recommend next manuscript to SCIRP and we will provide best service for you:

Accepting pre-submission inquiries through Email, Facebook, LinkedIn, Twitter, etc. A wide selection of journals (inclusive of 9 subjects, more than 200 journals) Providing 24-hour high-quality service

User-friendly online submission system

Fair and swift peer-review system

Efficient typesetting and proofreading procedure

Display of the result of downloads and visits, as well as the number of cited articles Maximum dissemination of your research work

Submit your manuscript at: http://papersubmission.scirp.org/

Or contact jss@scirp.org 